\title{
Directly observed reversible shape changes and hemoglobin stratification during centrifugation of human and Amphiuma red blood cells
}

\author{
Joseph F. Hoffman*† and Shinya Inoué ${ }^{*}$ \\ *Department of Cellular and Molecular Physiology, Yale University, New Haven, CT 06520; and ₹Marine Biological Laboratory, Woods Hole, MA 02543
}

Contributed by Joseph F. Hoffman, December 23, 2005

This paper describes changes that occur in human and Amphiuma red blood cells observed during centrifugation with a special microscope. Dilute suspensions of cells were layered, in a centrifuge chamber, above an osmotically matched dense solution, containing Nycodenz, Ficoll, or Percoll (Pharmacia) that formed a density gradient that allowed the cells to slowly settle to an equilibrium position. Biconcave human red blood cells moved downward at low forces with minimum wobble. The cells oriented vertically when the force field was increased and $\mathrm{Hb}$ sedimented as the lower part of each cell became bulged and assumed a "baglike" shape. The upper centripetal portion of the cell became thinner and remained biconcave. These changes occurred rapidly and were completely reversible upon lowering the centrifugal force. Bag-shaped cells, upon touching red cells in rouleau, immediately reverted to biconcave disks as they flipped onto a stack. Amphiuma red cells displayed a different type of reversible stratification and deformation at high force fields. Here the cells became stretched, with the nucleus now moving centrifugally, the $\mathrm{Hb}$ moving centripetally, and the bottom of the cells becoming thinner and clear. Nevertheless, the distribution of the marginal bands at the cells' rim was unchanged. We conclude that centrifugation, per se, while changing a red cell's shape and the distribution of its intracellular constituents, does so in a completely reversible manner. Centrifugation of red cells harboring altered or missing structural elements could provide information on shape determinants that are still unexplained.

centrifuge polarization microscope | Hb sedimentation | shape deformations

T his paper is concerned with red blood cells and changes in their shape and intracellular characteristics during centrifugation. These studies were carried out by use of a newly developed centrifuge polarizing microscope (CPM) (see Fig. 1), that provides, at high resolution, direct observation of the red blood cells, at speeds of up to $11,000 \mathrm{rpm}(1,2)$. It is known that centrifugation, per se, has essentially no effect on shape or volume when comparisons are made of human red cells before and after centrifugation. But it is not clear how these cellular parameters are affected during centrifugation with concomitant exposure to shear forces. In the present work, we describe the effects of centrifugation on single red blood cells of humans and Amphiuma with additional observations on human red cells in rouleau.

Human red blood cells are normally biconcave disks but, when exposed to shear stress, are known to become deformed, reversibly, as is evident when studied in a rheoscope (3), an ectocytometer (4), or during normal capillary flow. On the other hand, red blood cells in the spleen of rats $(5,6)$ and in clotted human blood (7), centrifuged at $400,000 \times g$ for $30 \mathrm{~min}$ before fixation and staining, showed elongation and, interestingly, stratification of $\mathrm{Hb}$ in the centrifugal ends. These results in rat red cells could reflect properties of the paracrystalline state of $\mathrm{Hb}$ in those cells (8). In neither rat nor human red cells were the shape transformations or the $\mathrm{Hb}$ stratifications reversible, results that differ from our observations reported below. Another approach to the deformability of human red cells during centrifugation is to compare the relative packing of "hardened" (acetaldehyde prefixed) red cells with normal red cells. The hardened human red cell pellets were found to contain $\approx 40 \%$ trapped medium, whereas the normal cells trapped $<1 \%$ (9). This finding was interpreted to indicate that normal cells, being more deformable, packed to a greater degree. A novel variation of this scheme involves centrifuging, horizontally, a dilute suspension of biconcave human red blood cells for $5 \mathrm{sec}(2-15,000 \times g)$ through a Teflon capillary tube into a $2 \%$ acetaldehyde fixation solution $(10,11)$. The idea was that any deformation of the cells that took place while in the capillary would be preserved on contact with the fixation solution. Typically, the centrifuged cells displayed rounded ends with stretched and somewhat triangular twisted tails with possible unequal distribution of $\mathrm{Hb}$. It is not clear in these experiments what the relationship was between the relative shapes of the cells and their time of fixation. Partial fixation and partial dilutions of the local fixation solution might have introduced sufficient time to alter whatever their cell shapes were while sedimenting in the capillary tube. In addition, it is not known what the orientation of the cells was with respect to the centrifugal field at the time they were fixed. All of abovementioned uncertainties of interpreting red cell shape resulting from exposure to a centrifugal field are removed in the present studies, because the cells were directly observed during their centrifugation. Also, the various shapes we saw were completely different from those described in any of the previously cited studies.

It has been known since the time of Malphighi, Swammardam, and Leuwenhock (see ref. 12) that human blood contained "red globules," which, with improved optics, segued into lenticularshaped cells $(13,14)$. That human red blood cells were, in fact, biconcave disks was definitively established in 1827 once the resolution of the microscope was improved by corrections for chromatic aberration (15). Rouleau formation of human red blood cells, in which cells are stacked one upon another like a roll of coins, was first seen in 1776 (16). Our results extend the catalog of classical shapes that human and Amphiuma red cells display in demonstrating the changes in form with attendant $\mathrm{Hb}$ stratifications that occur dynamically and reversibly during centrifugation.

\section{Results and Discussion}

This paper is primarily concerned with the alterations that red blood cells undergo as they are spun at various speeds in a centrifuge microscope. The cells are suspended in buffered saline solutions and centrifuged into an osmotically matched solution of a naturally formed density gradient composed of

Conflict of interest statement: No conflicts declared. Abbreviation: CPM, centrifuge polarizing microscope †To whom correspondence should be addressed. E-mail: joseph.hoffman@yale.edu. () 2006 by The National Academy of Sciences of the USA 


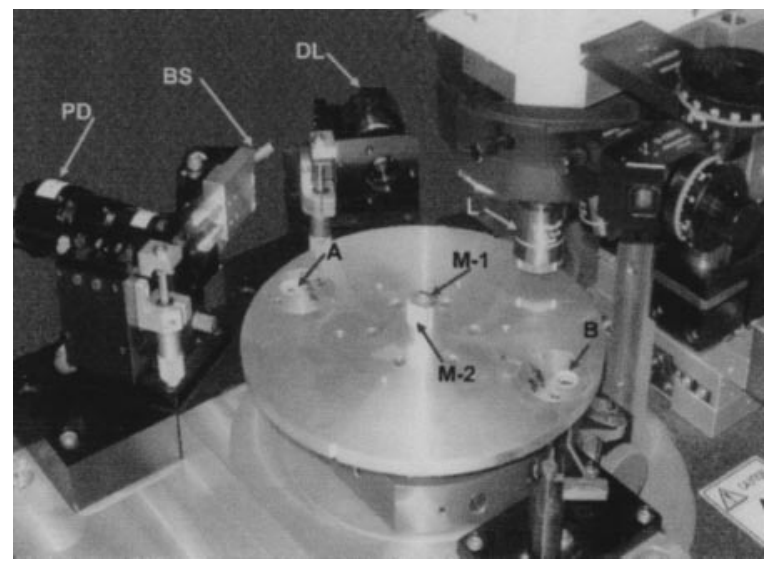

Fig. 1. CPM with dual-specimen chamber. To capture sequential sharp images of the specimen (spinning at peripheral velocities as high as $100 \mathrm{~m} / \mathrm{s}$ at $10,000 \mathrm{rpm})$, the light source [neodymium $(\mathrm{Nd})$-yttrium/aluminum garnet (Nd-YAG)] laser is made to fire a very brief pulse, exactly when the specimen (in chamber $A$ or $B$ ) comes under the objective lens (L). To provide exact registration of the sequential images with an image resolution of $0.5 \mu \mathrm{m}, \mathrm{a}$ photodiode (PD) triggers the NdYAG laser to fire a 6-ns pulse through a delay circuit that compensates for the rotor rpm. The PD, in turn, is triggered by light from the diode laser $(D L)$ reflected off a mirror (M-1 or M-2 located on the rotor post) that signals the rotor orientation (1). To distinguish the trigger signals for chambers $A$ and $B$, mirror $M-2$ is tilted to reflect the beam from the DL higher than $\mathrm{M}-1$. With the beam switcher (BS) in its higher position (as shown here), light reflected from $M-1$ passes below the $B S$ and reaches the PD, triggering the laser to fire when chamber $A$ is in position. With the BS in its lower position, the beam from $\mathrm{M}-1$ is blocked, while the beam from $\mathrm{M}-2$ is reflected to enter the PD by the two mirrors on the BS. That provides the trigger for viewing chamber $B$. Thus, one can instantly select to see the specimen in chamber A or B simply by flipping the BS (2). The inside dimension of the specimen chamber is $8 \mathrm{~mm}$ long (column height), $3 \mathrm{~mm}$ wide, and 0.5 $\mathrm{mm}$ thick. Approximately $10 \mu \mathrm{l}$ of solution (see Materials and Methods) was pipetted into a chamber for experimental observation. The upper window of the chamber is glass, and the lower is annealed acrylic, to cancel out the stress birefringence induced in the windows by the centrifugal force (1).

Nycadenz, Percoll, or Ficoll (Pharmacia). When centrifuged in the CPM at low speeds $(<1,000 \mathrm{rpm})$, human red blood cells are seen to orient either vertically or horizontally in the force field and to slowly move downward, seeking a position in the stationary density gradient (Fig. 2). The cells wobble somewhat as they descend but maintain their initial orientations without tumbling. The slight wobble of the red cells is presumably in response to the shear forces that the cells are subjected to as they move centrifugally. As the speed is increased $(>2,000-11,000 \mathrm{rpm})$, the cells become stationary upon reaching an equilibrium position in the pynotic/density layer and thus are free of any external fluid shear forces. In this situation, most cells orient vertically (Figs. $2 C-E, 3 B$, and $4 A-H$ ). There are two major changes in the cells' appearance as they are centrifuged at higher speeds. In one, the appearance of the cells changes because the $\mathrm{Hb}$ inside the cell sediments; in the other, there is a concomitant bulging of the lower portion of the cell, which pari passu assumes a "bag-like" shape. This occurs with the upper part of the red cell remaining biconcave (dimpled) albeit thinner, as well as brighter, due to the movement of $\mathrm{Hb}$ out of the upper space into the bag. This result indicates that the cell's biconcave shape is independent of the presence of $\mathrm{Hb}$. The sedimentation of $\mathrm{Hb}$ during centrifugation results from the force field overcoming the diffusibility of $\mathrm{Hb}$.

The stratification and shape changes are completely reversible, as shown in Figs. 2-5. As noted in the legend of Fig. 3B, human red cells attached to a coverslip during centrifugation show similar changes in shape and $\mathrm{Hb}$ sedimentation, as well as reversibility (Fig. 3C), as the cells in free suspension. One reason that these "sliding" cells are of interest is that comparable changes may obtain when cells are centrifuged in an angle-head rotor. It should be noted that all centrifugations took place at room temperature $\left(20-23^{\circ} \mathrm{C}\right)$, and that there is uncertainty regarding the degree of mixing of the cell suspension with its dense solution, due to uncontrolled convection and/or pipetting. Nevertheless, the cells in every case found an isopycnic boundary/position that varied somewhat across the lower layer of the centrifuge chamber. It also needs to be stated that all of the attendant changes in cell shape and $\mathrm{Hb}$ distribution seen in Nycodenz solutions were also seen when the dense solution contained either Ficoll (data not shown) or Percoll (Fig. 4).

In contrast to human, Amphiuma red cells undergo cellular elongation with $\mathrm{Hb}$ moving upward (centripetally) rather than downward, with a concomitant bulging of the upper part of the cell, as shown in Fig. 5. The nucleus is seen to move downward into a relatively clear cytoplasm. Because of the ability to analyze the birefringence of these cells during their centrifugation, the structural orientation of the marginal bands (17) can clearly be visualized surrounding the internal periphery of the cells, as noted in the legend. Here again, with reduction of the centrifugal force field, the changes in cell shape, nucleus, and $\mathrm{Hb}$ distribution were reversible.

A question of interest is to what extent does the centrifugation (force field) per se have an effect on human red blood cells, knowing that the steady-state volume of the cells is not affected by centrifugation? It should be understood that, at the highest speeds used $(11,700 \mathrm{rpm})$, the hydrostatic pressure head at the bottom of the centrifuge chamber is $<5$ atmosphere (atm) (1 atm $=101.3 \mathrm{kPa}$ ), with, of course, there being no net pressure gradient across the cell. Human red blood cells are known to be essentially incompressible $\left[3.4 \times 10^{-11} \mathrm{~cm}^{2} /\right.$ dyne $(1$ dyne $=10$ $\mu \mathrm{N} ;$ ref. 18)]. Centrifugation of red blood cells between $20,000 \times$ $g$ and $190,000 \times g$ decreases the hematocrit of packing by $1.7 \%$ and between $40,000 \times g$ and $190,000 \times g$ by $0.7 \%$ (19). These decreases presumably represent changes in the volume of serum lodged between the cells, although it is not known that the hematocrit value, i.e., the packed cell volume, is the same during centrifugation as it is afterward when the measurements are made. It is also known (20) that $\mathrm{Hb}$ exists inside the cell in random orientation that persists for small perturbations of cell volume, such as those that took place $( \pm 10 \%)$ in the conditions underlying the results presented in Figs. 2 and 3. The red cells under these conditions are also known to act as perfect osmometers (21). Whether these comments apply to Amphiuma red cells is currently not known. Of note, the fragmentation and stratification reported for the red cells of Necturus and frogs when centrifuged at forces between 20,000 and $400,000 \times g(22)$ were not seen in the present work.

The rouleau formation seen in Fig. 4 took place when the dense solution contained Percoll [polyvinylpyrrolidone (PVP)]. Rouleau is seen in normal human blood, and the physiologic promoter for its formation is the presence of fibrinogen. Many types of uncharged polymers, such as PVP, Dextrans, and polyethylenglycols, are also known to stimulate rouleau formation. Nevertheless, there is no agreement on the mechanism(s) that underlies rouleau formation. The distance between the stacked cells has been shown to vary directly with the size of the inducing agent (23), but it is not known to what extent the glycocaylyx, present on the surface of human red blood cells, is involved $(23,24)$. Neurominidase treatment of human red cells causes accelerating rouleau formation by reducing their surface charge and electrophoretic mobility. ${ }^{\S}$ On the other hand, treatment of cells with $4,4^{\prime}$-diisothio-cyanatostilbene-2,2' -disulfonic

§Jan, K.-M. \& Chien, S. (1972) Fed. Proc. 31, 341. 

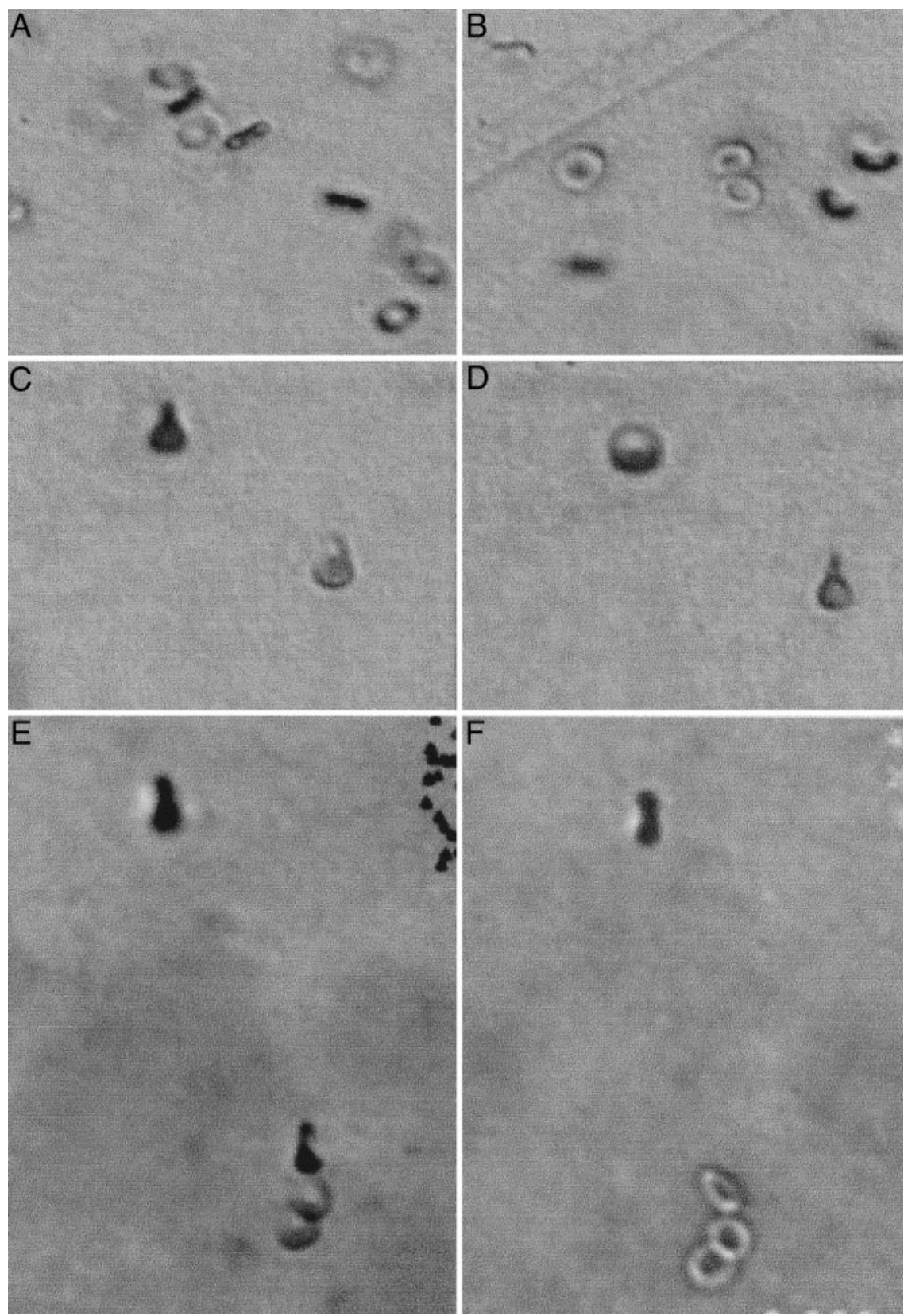

Fig. 2. Hb sedimentation and shape changes of human red bloods during centrifugation and their reversibility. A dilute suspension of human red blood cells in buffered hypotonic saline (solution A) was laid onto the top of a dense solution of Nycodenz in the centrifuge chamber (see Materials and Methods). During the initial centrifugation at $700 \mathrm{rpm}(A)$, in which the centrifugal force is down (as in Figs. 2-5), the depicted biconcave disks were seen to sediment in either a vertical or horizontal orientation (parallel or perpendicular with respect to the force field). The cells in either orientation tended to wobble slowly but not tumble. When the speed was increased to $2,000 \mathrm{rpm}(B)$, the cells remained in their same orientations, but some of the cells became cup-shaped, with the bottom of the cup pointing centrifugally. At higher speeds of rotation $(8,700 \mathrm{rpm})$, the cells oriented vertically $(C$ and $D)$, and it is evident that the $\mathrm{Hb}$ molecules sediment toward the bottom of each cell, so that the cell acquires a prominent bulge. At the same time, the upper part of the cell became or stayed a thin half disk that still is biconcave. Hence the whole cell takes on a "bag" shape. $D$ shows, 17 sec later, that the same two cells seen in $C$ have turned and are now seen in different perspectives. The cells displayed are free-floating and not in contact with either cover plate. $E(9,700 \mathrm{rpm})$ shows four bag-shaped cells in different views. $F$, 100 sec later, shows that the same cells seen in $E$ return to their normal biconcave disk shape after the speed is markedly reduced ( $400 \mathrm{rpm})$. Depending on the focal level, the thinner biconcave region of the cell may appear brighter or darker than the thicker (light-absorbing and refractive) regions. These results show that the alterations in shape and $\mathrm{Hb}$ distribution induced by the centrifugal force are completely reversible.

acid (DIDS), which is known to inhibit anion transport by Band 3 , inhibits rouleau formation, presumably by adding net charge or repulsive force to the interface (26). In contrast, rouleau formation with dextrans is known to be biphasic, independent of the size of the dextran used $(27,28)$, with the interesting result that the dextran polymers change their structure (i.e., coil to network) as a function of concentration and the peak of the biphasic response correlates with the transition in the dextran's molecular structure (28). Evidently, there is no specificity in agents that induce rouleau formation, so long as minimum requirements are met (e.g., ref. 29). On the other hand, the mechanisms(s) and the detailed chemistry responsible for the interaction and the stacking phenomenon have yet to be defined. It is also not clear what forces underlie the shape changes of the 

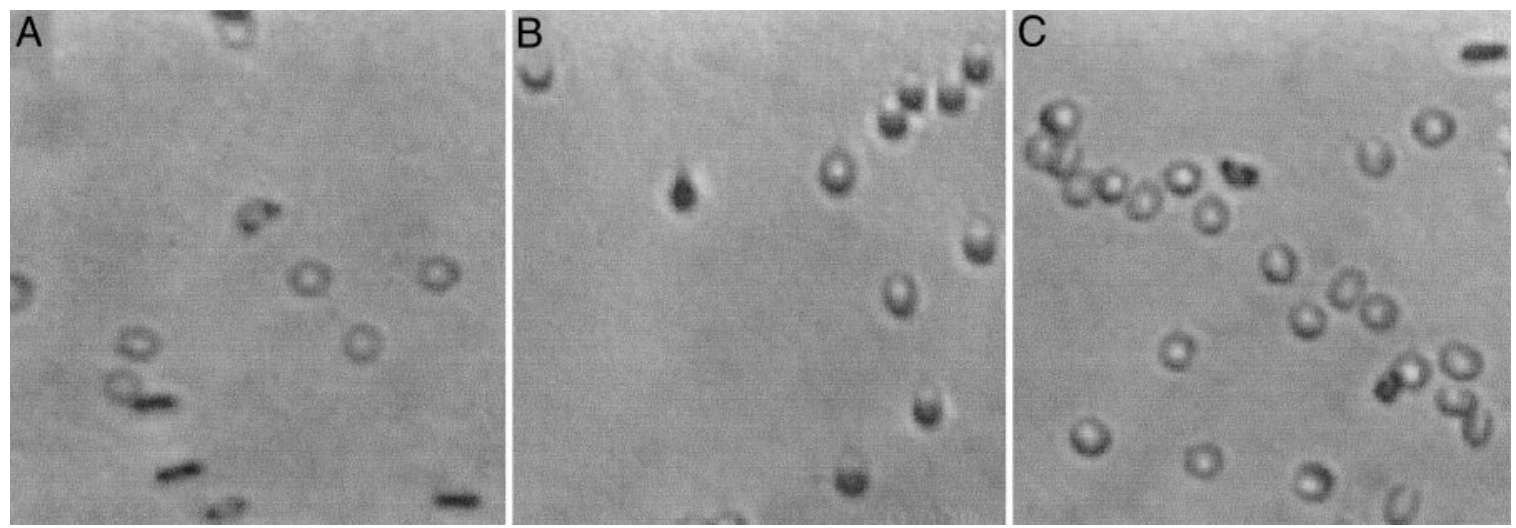

Fig. 3. Displacement and deformation of human red blood cells attached to the bottom plastic window of the chamber. The human red cells were suspended in a hypertonic saline/Nycodenz medium (see Solution B in Materials and Methods) in which many of the cells were allowed to settle and attach on the lower (plastic) window of a chamber before rotation of the centrifuge. At low centrifugal force $(2,000 \mathrm{rpm})$, the biconcave cells seen en face $(A)$ are attached to the window and display uniform $\mathrm{Hb}$ distribution. The unattached cells sediment horizontally as seen in Fig. 2 . As the speed of rotation was increased (9,700 rpm), the centrifugal force sediments the $\mathrm{Hb}$ and stretched the attached cells $(B)$, which become narrower and more extremely bag-shaped as they glide down the surface of the window. C shows that, as the speed was decreased to $400 \mathrm{rpm}$, the cells that remained attached to the surface regained their symmetric biconcave shape.

red cells as they attach and flip onto the stack, as depicted in Fig. 4 , but it would appear that the rouleau forces that drive the maximal surface contacts between cells in a stack are stronger than the centrifugal forces responsible for the distortion of the cell's shape.
The experimental results reported here have been mainly concerned with the deformability of human and Amphiuma red blood cells that occur during their centrifugation. Although we were surprised that the centripetal region of the bag-shaped human red cells still remained biconcave, the results do not
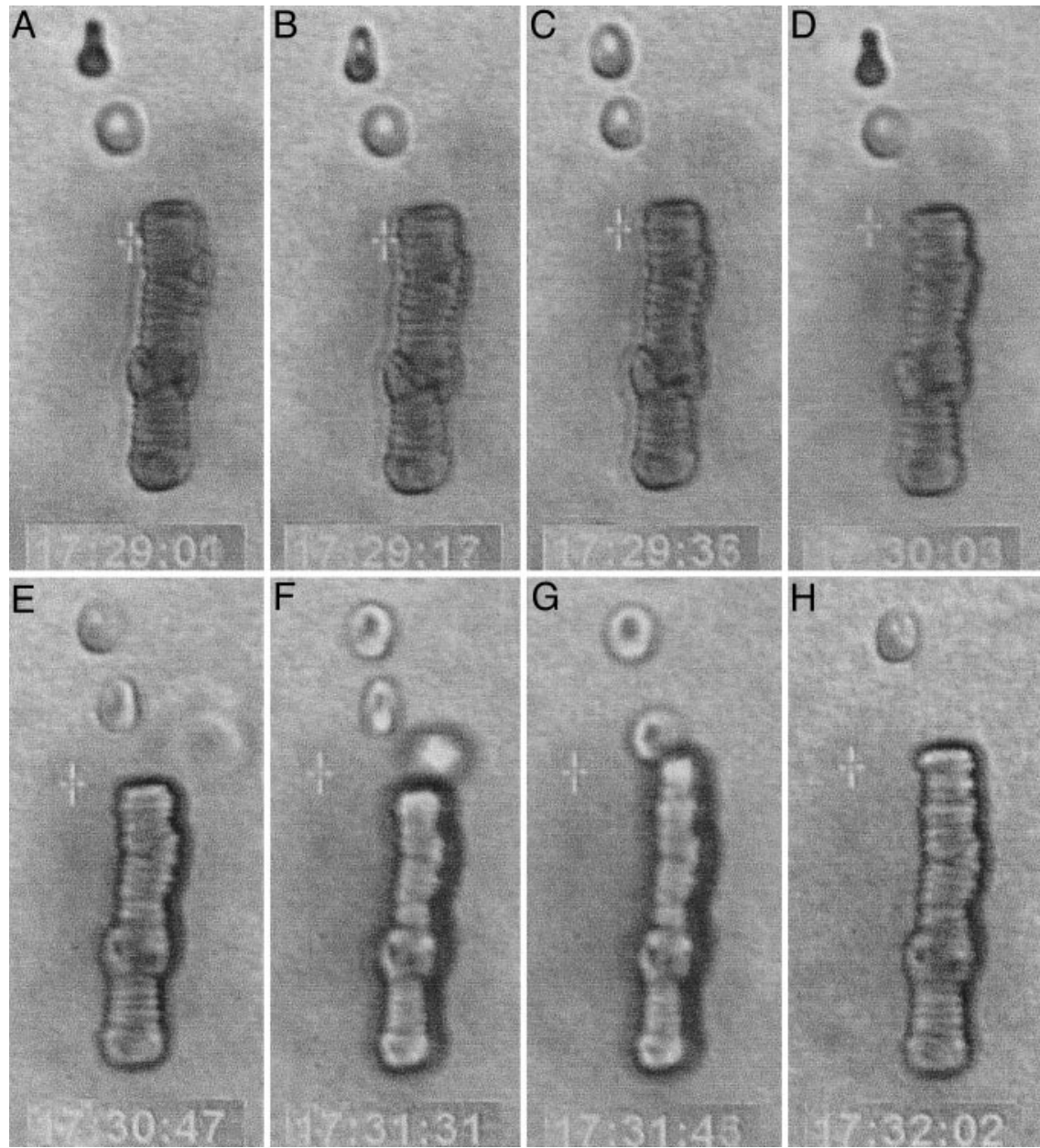

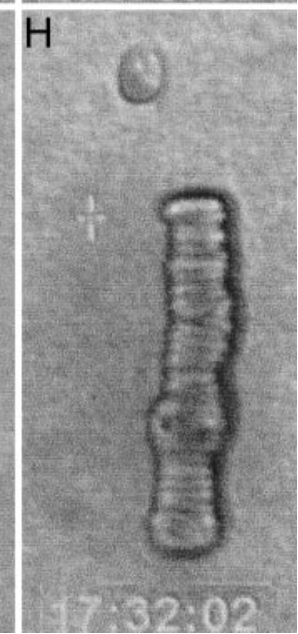

Fig. 4. Rouleau formation. Shown is a timed sequence of two bag cells adding to the top of a stack of human red cells in rouleau formation. The speed is $4,800 \mathrm{rpm}$ and the time of day, shown in the bottom, is in h:min:sec. The cells were suspended in an isotonic saline/Percoll medium (see Solution C in Materials and Methods). It should be noted that this rouleau was only seven cells tall $10.5 \mathrm{~min}$ before that seen in $A$; in the meantime, cells were added to both its top and bottom. In $A-G$, two bag-shaped cells above the rouleau can be seen in different views as they turn. (Depending on the focal level, the contrast of the thicker and thinner parts can be reversed.) In $E-G$, a third cell, which is out of focus, approaches from the right and joins the stack at the top. In $G$ and $H$, the lower of the two original bag-shaped cells became incorporated into the rouleau. As soon as the bag-shaped cell touches the stack, it loses its asymmetric shape and unequal $\mathrm{Hb}$ distribution and resumes its original biconcave disk shape as it flips onto the top. (Taking $A$ as zero time, $B-H$ represent, respectively, $17,36,63,107$, 151,165 , and $182 \mathrm{sec}$ later.) 

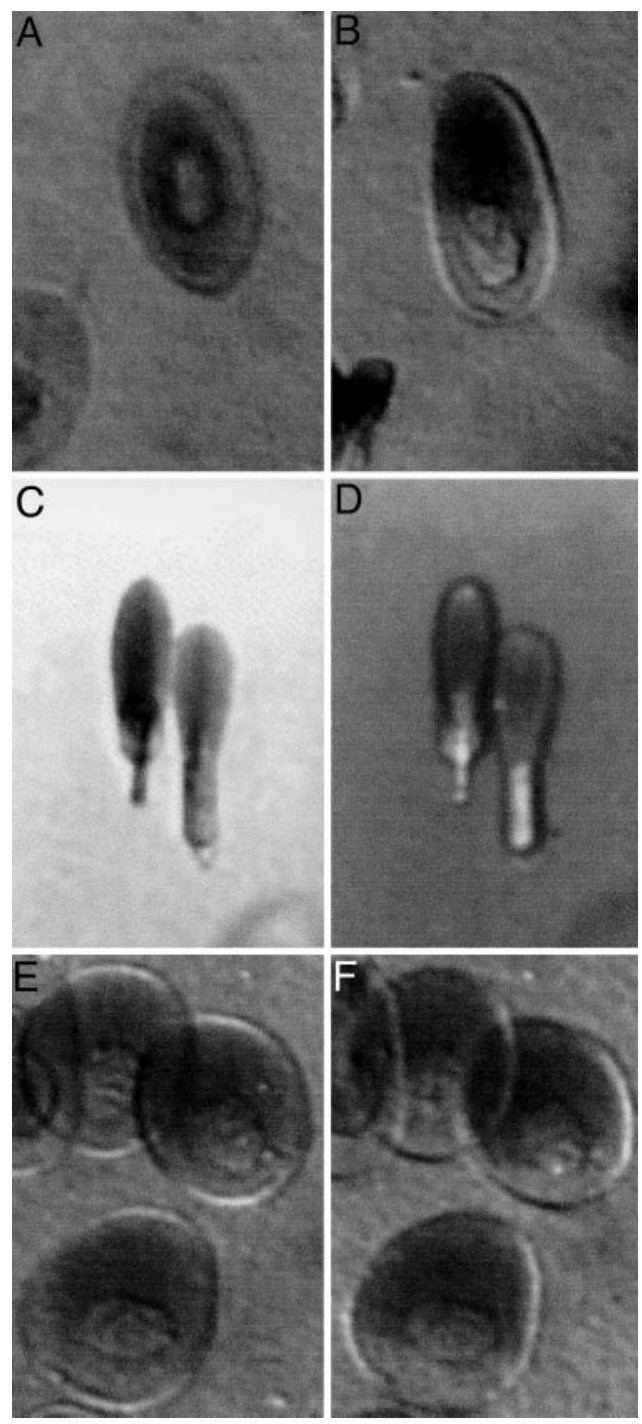

Fig. 5. The effect of centrifugation on Amphiuma red blood cells. Am phiuma red cells were suspended in an isotonic amphibian Ringer/Ficoll solution, as described in Materials and Methods. A shows two cells, sedimenting at low speed $(1,000 \mathrm{rpm})$, in which the nucleus is located centrally in each cell similar to their appearance at $0 \mathrm{rpm}$. $B$ shows that under increased centrifugal force $(11,700 \mathrm{rpm})$, the red cells elongate as the $\mathrm{Hb}$ stratifies upward, leaving a thin clear lip below, while the nucleus moves down. The descending nucleus tends to be deformed as though still partially anchored to the middle of the cell. The microtubules in the marginal band remain at the periphery of the cell, despite the extreme deformation of the cell. $C$ and $D$ show side views of two other cells also being centrifuged at 11,700 rpm. $E$ and $F$ show Amphiuma red cells $\approx 18 \mathrm{~min}$ after reduction of the speed to $200 \mathrm{rpm}$. Here the cells display their reversibility, having returned to become roundish disks with their $\mathrm{Hb}$ being almost equally distributed and their nuclei having moved toward the middle of the cells. Typically, as shown, the cells are oriented vertically during their centrifugation. $\ln B, D$, and $F$, the birefringent marginal band appears bright vertically and dark horizontally, whereas in $C$ and $E$, they appear in reverse contrast. The contrast is due to the interaction of the positive birefringence of the microtubules (that make up the marginal band) with the Brace-Koehler compensator, whose orientation is reversed between $C$ and $E$.

address the interesting and important property of cell shape, particularly the nature of the biconcave disk that characterizes these cells (see ref. 30). The centrifuge microscope could be a useful device to further investigate the basis for the biconcave shape of human red cells by testing the effects of various agents (e.g., DIDS, Diamide, and wheat and germ agglutinin) on cell deformation during centrifugation. The study of human (and mouse) red cells in which abnormalities in their cytoskeletal and surface structures have been characterized (e.g., knockouts and missing or altered cytoskeletal and/or membrane constituents) could provide insight into the molecular basis for the disk shape and cellular elements involved. It is hoped that studies such as these will soon be forthcoming.

\section{Materials and Methods}

Red Cell Preparations. Normal human blood was taken by finger puncture, collecting either the third or fourth drop into $3 \mathrm{ml}$ of a heparinized isotonic solution (310 mosM) that contained 150 $\mathrm{mM} \mathrm{NaCl}, 20 \mathrm{mM}$ Tris. $\mathrm{Cl}$, and $0.2 \% \mathrm{BSA}(\mathrm{pH} 7.4)$ at $23^{\circ} \mathrm{C}$. The cells were then sequentially diluted $\approx 50,000$-fold into either the same solution or a solution in which the concentration of $\mathrm{NaCl}$ was changed to either $125 \mathrm{mM}$ (hypotonic, 272 mosM) or 175 $\mathrm{mM}$ (hypertonic, 353 mosM). Three to five microliters of these diluted cell suspensions, containing 100-300 red blood cells, was then pipetted into a centrifuge chamber (see below) and carefully layered on top of $5 \mu \mathrm{l}$ of a dense solution. The dense solutions were as follows: Solution A, hypotonic: $17 \mathrm{mM} \mathrm{NaCl} /$ $0.8 \mathrm{mM} \mathrm{KCl} / 0.3 \mathrm{mM} \mathrm{CaCl} / 3.2 \mathrm{mM}$ 4-morpholinepropanesulfonic acid ( $\mathrm{pH} 7.3$ at $\left.23^{\circ} \mathrm{C}\right) / 1.40 \mathrm{~g}$ of Nycodenz (Sigma) per $5 \mathrm{ml}$ of solution $\left(275 \mathrm{mosM}\right.$, density $1.126 \mathrm{~g} / \mathrm{ml}$ at $\left.23^{\circ} \mathrm{C}\right)$. Solution B, hypertonic: the same as Solution A, except that the concentration of Nycodenz was $1.80 \mathrm{~g}$ per $5 \mathrm{ml}$ of solution (351 mosM, density $1.162 \mathrm{~g} / \mathrm{ml}$ ). Solution $\mathrm{C}$, isotonic: $130 \mathrm{mM} \mathrm{NaCl} / 15 \mathrm{mM}$ Tris. $\mathrm{Cl}\left(\mathrm{pH} 7.3\right.$ at $\left.23^{\circ} \mathrm{C}\right) / 90 \%$ Percoll (wt/vol; Sigma)/302 mosM; density, $1.130 \mathrm{~g} / \mathrm{ml}$. The osmolality of the dense solutions matched those saline solutions in which the cells were suspended.

Red blood cells of the three-toed salamander, Amphiuma tridactylum, were obtained by cardiac puncture as described (31). These are giant nucleated elliptical red blood cells, 150 times the volume of human red blood cells $\left(87 \mu \mathrm{m}^{3}, 6-8 \mu \mathrm{m}\right.$ diameter) whose average dimensions are $61 \mu \mathrm{m}$ in length, $36 \mu \mathrm{m}$ in width, and the thickness of the cell $15 \mu \mathrm{m}$ across the nucleus compared with $8 \mu \mathrm{m}$ for the cytoplasm. The cells were treated essentially as described above for human red cells but were washed (by spontaneous settling) in a modified isotonic (201 mosM) amphibian Ringer solution whose composition was $95 \mathrm{mM} \mathrm{NaCl} /$ $2.5 \mathrm{mM} \mathrm{KCl} / 1.8 \mathrm{mM} \mathrm{CaCl} / 0.2 \%$ BSA/10 4-morpholinepropanesulfonic acid ( $\mathrm{pH} 7.0$ at $23^{\circ} \mathrm{C}$ ). After suitable dilution (two steps) of the cells in this solution, 3-5 $\mu$ l of the final suspension containing $\approx 200-300$ cells was pipetted onto the top of a dense solution, as described before. The isotonic dense solution contained Ficoll70 (70,000 $M_{\mathrm{r}}$, Sigma) in a concentration of $25 \mathrm{~g}$ Ficoll in $40 \mathrm{ml}$ of a 1/10 dilution of the wash medium (200 mosM; density, $1.1502 \mathrm{~g} / \mathrm{ml}, \mathrm{pH} 7.0$, at $23^{\circ} \mathrm{C}$ ).

It should be understood that the composition of the dense solutions was primarily dictated by the requirements of osmolarity and density to provide a buoyant medium and density gradient that optimized viewing and minimized cell volume changes.

CPM. The CPM, developed jointly by Olympus (Melville, NY), Hamamatsu Phototonics ( (Hamamatsu City, Japan), and the Marine Biological Laboratory, allows video microscopic observation and recording of intracellular constituent stratification and molecular alignment in living cells spinning at between 100 and $11,700 \mathrm{rpm}$. Through a special timing circuit, the specimen is momentarily illuminated by a 532-nm wave-length 6-ns laser pulse exactly as it traverses below the objective lens. With a $40 \times$ 0.55-numerical aperture-long working-distance objective lens, the image is resolved to somewhat better than $1 \mu \mathrm{m}$ (1). By manually switching a timing-trigger control device (added since the original design), one can observe the specimen placed in either one of the two chambers in sequence with no delay (ref. 2; Fig. 1). 
Contrast of the specimen placed in the chambers, whose windows are designed to suffer only low degrees of stress birefringence, can be generated in bright field, in polarization optics with a sensitivity exceeding $1 \mathrm{~nm}$ in retardation, in differential interference contrast (Nomarski contrast), or in fluorescence excited by the 532-nm neodymium-yttrium/ aluminum garnet laser illumination (32). Human red cells were generally observed with the compensator rotated sufficiently away from extinction, in other words, essentially as bright-field images, whereas the Amphiuma cells were observed either in bright field (Fig. 5A) or with appropriate compensation to display the birefringence of the microtubule bundles that make up the marginal band (Fig. $5 B-F$ ).

The human and Amphiuma red blood cells, suspended in solutions as described above, were observed in the CPM rotating at between 200 and 11,700 $\mathrm{rpm}(3.4 \times g$ to $11,500 \times g$, where $g=$

1. Inoué, S., Knudson, R.A., Goda, M., Suzuki, K., Nagano, C., Okada, N., Takahashi, H., Ichie, K., Iida, M. \& Yamanaka, K. (2000) J. Microsc. 201, 341-356.

2. Knudson, R.A., Inoué, S. \& Goda, M. (2001) Biol. Bull. 201, 234.

3. Fischer, T. M., Stöhr-Liesen, M. \& Schmid-Schönbein, H. (1978) Science 202, 894-896.

4. Bessis, M. \& Mohandas, N. (1975) Blood Cells I, 307-313.

5. Beams, H. W. \& Kessel, R. G. (1966) Anat. Rec. 155, 541-550.

6. Beams, H. W. (1947) Proc. Soc. Exp. Biol. Med. 66, 373-375.

7. Skalak, R. \& Branemark, P.-I. (1969) Science 164, 717-719.

8. Ponder, E. (1948) Hemolysis and Related Phenomena (Grune and Stratton, New York).

9. Chien, S., Dellenback, R. J., Usami, S., Seaman, G. V. F. \& Gregersen, M. I. (1968) Proc. Soc. Exp. Biol. Med. 127, 982-985.

10. Corry, W. D. \& Meiselman, H. G. (1978) Biophys. J. 21, 19-34.

11. Corry, W. D. \& Meiselman, H. J. (1978) Blood 51, 693-701.

12. Bessis, M. \& Delpech, G. (1981) Blood Cells 7, 447-480.

13. Sénac, M. (1749) in Traité de la Structure du Coeur (Briasson, Paris), pp. $654-670$.

14. Gulliver, G. (1846) The Works of William Henson (Sydesham Society, London), Vol. 2, pp. 209-291.

15. Hodgkin, T. \& Lister, J. J. (1827) Philos. Mag. 2, 130-138.

16. Della Torre, G. M. (1776) in Nuove Osservazioni Microscopiche (C. R. Somasco, Napoli, Italy), pp. 1-135.
Earth's gravitational acceleration). Data were analyzed by repeated playback of the video sequences at various speeds and by listening to the real-time audio comments made on the videotape during observation.

It is important to mention that, in interpreting the shape of the red blood cells from their images in conventional bright-field microscopy, individual unstained cells do not appear red at all. This is because they are so thin that refraction, rather than absorption by $\mathrm{Hb}$, contributes primarily to the contrast of the image. Even in the green light used in our CPM, the thicker portions of the biconcave cell appear dark only at exact focus. As the focus is shifted, the contrast reverses by refraction effects as in the "Becke line" phenomena (see ref. 25).

We thank Dr. Makoto Goda and Bob Knudson for input to and improvements of the CPM and Hamamatsu Photonics and Olympus for major contributions to the development of the CPM.

17. Cohen, W. D. (1978) J. Cell Biol. 78, 260-273.

18. Weiser, M. A. H. (1981) Ph.D. thesis (Yale Univ., New Haven, CT)

19. Parpart, A. K. \& Ballentine, R. (1943) Science 98, 545-547.

20. Bateman, J. B., Hsu, S. S., Knudsen, J. P. \& Yudowitch, K. L. (1953) Arch. Biochem. Biophys. 45, 411-422.

21. Freedman, J. C. \& Hoffman, J. F. (1979) J. Gen. Physiol. 74, 157-185.

22. Beams, H. W. \& King, R. L. (1945) J. Morphol. 77, 63-69.

23. Chien, S. \& Jan, K.-M. (1973) Microvasc. Res. 5, 155-166.

24. Neu, B. \& Meiselman, H. J. (2002) Biophys. J. 83, 2482-2490.

25. Chamot, E. M. \& Mason, C. W. (1958) in Handbook of Chemical Microscopy (Wiley, New York), 3rd Ed., pp. 314-315.

26. Norris, S. S., Allen, D. D., Neff, T. P. \& Wilkinson, S. L. (1996) Transfusion 36, 109-112.

27. Evans, E. A. \& Parsegian, V. A. (1983) in Annals of the New York Academy of Sciences, eds. Copley, A. L. \& Seaman, G. V. F. (New York Academy of Sciences, New York), Vol. 416, pp. 13-33.

28. Barshtein, G., Tamir, I. \& Yedgar, S. (1998) Eur. Biophys. J. 27, 177-181.

29. Armstrong, J. K., Wenby, R. B., Meiselman, H. J. \& Fisher, T. C. (2004) Biophys. J. 87, 4259-4270.

30. Hoffman, J. F. (2001) Blood Cells Mol. Dis. 27, 57-61.

31. Hoffman, J. F. \& Geibel, J. P. (2005) Proc. Natl. Acad. Sci. USA 102, 921-926.

32. Inoué, S., Goda, M. \& Knudson, R. A. (2001) J. Microsc. 201, 357-367. 